\title{
Article \\ A Long-Term Analysis of the Possibility of Water Recovery for Hydroponic Lettuce Irrigation in an Indoor Vertical Farm. Part 2: Rainwater Harvesting
}

\author{
Anna Jurga ${ }^{1}$, Anna Pacak ${ }^{2, *}$, Demis Pandelidis ${ }^{2}$ and Bartosz Kaźmierczak ${ }^{3}(\mathbb{D}$ \\ 1 Department of Environmental Protection Engineering, Faculty of Environmental Engineering, \\ Wroclaw University of Science and Technology, 50-370 Wroclaw, Poland; anna.jurga@pwr.edu.pl \\ 2 Department of Cryogenics and Aerospace Engineering, Faculty of Mechanical and Power Engineering, \\ Wroclaw University of Science and Technology, 50-370 Wroclaw, Poland; demis.pandelidis@pwr.edu.pl \\ 3 Department of Water Supply and Sewerage Systems, Faculty of Environmental Engineering, \\ Wroclaw University of Science and Technology, 50-370 Wroclaw, Poland; bartosz.kazmierczak@pwr.edu.pl \\ * Correspondence: anna.pacak@pwr.edu.pl
}

check for updates

Citation: Jurga, A.; Pacak, A.; Pandelidis, D.; Kaźmierczak, B. A Long-Term Analysis of the Possibility of Water Recovery for Hydroponic Lettuce Irrigation in an Indoor Vertical Farm. Part 2: Rainwater Harvesting. Appl. Sci. 2021, 11,310. https://doi.org/10.3390/ app11010310

Received: 24 November 2020 Accepted: 28 December 2020 Published: 30 December 2020

Publisher's Note: MDPI stays neutral with regard to jurisdictional clai$\mathrm{ms}$ in published maps and institutional affiliations.

Copyright: (C) 2020 by the authors. Licensee MDPI, Basel, Switzerland. This article is an open access article distributed under the terms and conditions of the Creative Commons Attribution (CC BY) license (https:// creativecommons.org/licenses/by/ $4.0 /)$.
Featured Application: The presented analysis allows one to evaluate the use of rainwater for the purposes of watering plants for indoor cultivation halls potentially located in Wrocław (Poland, Lower Silesia).

\begin{abstract}
The aim of this study was to determine the suitability of a rainwater harvesting system to cover the water demand for indoor hydroponic lettuce cultivation located in Wrocław (Poland). The analysis was performed on the basis of the recorded rainfall in Wrocław in 2000-2019. The analyzed cultivation is located in a hall with an area of $300 \mathrm{~m}^{2}$, where the lettuce is grown vertically by the hydroponic method. The calculations of the rainwater harvesting ( $\mathrm{RWH}$ ) system were carried out considering the selection of the tank capacity for the collected water. The operation of the water storage is simulated using a yield after spillage (YAS) algorithm. It was evident that the proposed system might be an auxiliary system that relieves the water supply network or supports other water recovery systems (e.g., the water vapor condensation in a cross-flow heat exchanger operating as an element of the air conditioning system, proposed in Part 1 of this study). The harvesting system for the selected vertical farming indoor hall covers an average of $35.9 \%$ of water needs and allows a saving of $146,510 \mathrm{~L}$ of water annually for the cultivation. An average water demand coverage increases up to $90.4 \%$, which allows a saving of 340,300 L per year when the RWH system is combined with water recovery from exhaust air from the hall.
\end{abstract}

Keywords: rainwater; rainwater harvesting; rainfall trends

\section{Introduction}

In recent years, indoor vertical farming has become increasingly popular, as a means of sustainable development in the agricultural sector. Avgoustaki and Xydis (2020) [1] have listed several global issues that have accelerated the expansion of urban farming (i.e., vertical farming): increasing $\mathrm{CO}_{2}$ emissions, water pollution, over-fertilization, deforestation, loss of arable land, food security, and energy storage. However, many important factors need to be taken into account in order to create a truly sustainable place of food production. Usually, soilless cultivation is used in such places. It allows plants to be grown in aqueous nutrient solutions without using soil. Compared to conventional soil-based plant production, these technologies are more expensive in terms of investment and service cost but offer many advantages. The lack of soil use reduces the risk of transmission of pathogens. It enables greater control over cultivation parameters and the composition of the fertilizer used. In addition, lower water and fertilizer consumption, combined with 
the possibility of using a larger crop density, simply makes this method more efficient and effective than with soil [2]. As is evident, the soilless technology itself requires proper optimization to be more sustainable. Other considerations include water supply system, ventilation, HVAC (Heating, Ventilation, Air Conditioning), indoor air circulation, nutrient sanitation, and lighting. In each of these fields, some novel design and technological approaches can be taken. Various aspects of vertical farming were extensively reviewed in Kalantari et al. [3].

In this article, the main focus is on a sustainable water source for indoor vertical farming. The first part of the study (a long-term analysis of the possibility of water recovery for hydroponic lettuce irrigation in an indoor vertical farm. Part 1: Water recovery from exhaust air [4]) analyzed a simple system of water recovery from exhaust air using a cross-flow exchanger. This method of water recovery only partially provides a water supply for irrigation throughout the year and therefore still depends on an external water supply for irrigation. This is disadvantageous because, in Poland, the water resources are relatively low when compared to the European average. According to Canales et al. [5], the Polish average water resources per capita equals $1600 \mathrm{~m}^{3}$ while the European average $\left(4800 \mathrm{~m}^{3}\right)$ is three times higher. Climate change and global warming affect the fresh water availability [6], hence the Polish water resources are constantly decreasing. With population growth and water usage, there is a risk that the country will have to face water shortages in the future [5]. Poland is located in a temperate climate in which rains are observed throughout the year. The highest average annual rainfall is over $1000 \mathrm{~mm}$ in the mountains, while in the lowlands it is between $450-650 \mathrm{~mm}$ (563 $\mathrm{mm}$ in Wrocław). In those regions, water harvesting may be proposed as an alternative solution for water recovery for various purposes in households, and in industrial and residential buildings. In addition, water harvesting systems have the advantages of saving energy for pumping raw water $[7,8]$, relieving drainage, and reducing the risk of local flooding $[5,9,10]$.

In fact, such a solution is used in many places, including greenhouses and vertical farms. For instance, in the Trento AgroFarm project rainwater is collected and recovered to the fertigation system, and for non-potable usage (e.g., for the air treatment unit) [11]. Other examples of rainwater reuse for urban agriculture purposes are reported in [12]. Rainwater is used for maize cultivation [13], lettuce and tomato production [14], olive gardens irrigation [15], lawn irrigation [12,16], and various other crops and horticulture cultivation $[15,17]$. Besides the urban application, rainwater harvesting is applied in rural areas. Parson et al. [18] suggested that the use of reclaimed water might decrease domestic water consumption in the UK, and thus lower the demand for potable water. The review concludes that the main trends in this field of research are: water savings, water quality, stormwater control, and recently sustainable resource use. In rural areas rainwater might be re-used for toilet flushing or garden irrigation [18].

Conserving water is necessary due to it being constantly limited. Additionally, there is a growing popularity for indoor crops, which require the adaptation of various systems (water recovery systems, HVAC systems) depending on the type of crop and its location. The numerous analyses of rainwater recovery systems for various locations around the world show the importance of this topic. It is important to conduct this type of analysis because water recovery in various regions of the world is becoming more and more popular and it encourages entrepreneurs to implement new technologies.

The performance and design of RWH systems have been investigated using different approaches, including water balance simulation analyses and mass curve analyses, probabilistic methods, and economic optimization [19]. The results indicate that the storage capacity of tanks cannot be standardized but is considerably influenced by local rainfall, catchment surface characteristics, and type of harvested rainwater management. Calculation modules make use of the various mass balance simulation schemes. Basic modeling approaches of "yield after spillage" (YAS) and "yield before spillage" (YBS) have been used in many models in the context of RWH. Research studies have been devoted to the selection of the appropriate simulation time step to enable a realistic representation of the 
results of mass balances. Several authors analyzed water-saving efficiency by modeling the RWH system at a range of time intervals (hourly, daily, and monthly) with the YAS and YBS operating rules tested. General conclusions support the use of the YAS operating algorithm for design purposes as it results in a more conservative estimate of water-saving efficiency [20]. Water efficiency modeling approaches within RWH tools have been widely shown to give accurate representations when daily time-step intervals are used [21,22].

The aim of this study is to determine if the rainwater harvesting system itself, and in combination with water recovery from the exhaust air by a cross-flow exchanger operating in the air-conditioning system is sufficient to cover the water demand for hydroponic lettuce cultivation located in Wrocław (Poland). The analysis was performed on the basis of the recorded rainfall in Wrocław in 2000-2019, and the hourly meteorological data (the temperature, the humidity, and the atmospheric pressure) recorded in Wrocław in 2012-2019. The calculations of the rainwater recovery system were carried out, taking into account the selection of the reservoir for the collected water, as well as, the cost-benefit analysis for other alternative tank capacities. This study determines the share of water which can be covered by the rainwater harvesting system, and in association with the exhaust air water vapor recovery system over the years, in addressing the demand for irrigation of lettuce. The proposed system is an auxiliary system that relieves the water supply network or other water recovery systems.

\section{Materials and Methods}

\subsection{Meteorological Data}

The rainfall pattern is the main indicator of rainwater harvesting potential in Poland. This paper analyses a set of 20-year long time-series of daily rainfall (from 2000 to 2019) in Wrocław. The daily time step was chosen due to the very long simulation period. The source of precipitation data are the records by the meteorological station, WrocławStrachowice (the highest-order meteorological station type in Poland) managed by the Institute of Meteorology and Water Management-National Research Institute. The course of annual and average monthly rainfall amounts in Wrocław in the analyzed period is shown in Figure 1.

The average annual rainfall in the analyzed period was $541 \mathrm{~mm}$, with the highest annual rainfall of $723.5 \mathrm{~mm}$ recorded in 2009, and the lowest amounting to $388.3 \mathrm{~mm}$ in 2015. Figure 2 shows that the highest average monthly rainfall occurs in the summer season, from May $(\mathrm{V})$ to October $(\mathrm{X})$, and within a range from $37.1 \mathrm{~mm}(\mathrm{X})$ to $94.9 \mathrm{~mm}(\mathrm{VII})$. In the colder half-year, from November (September) to April (April), the average monthly rainfall ranges from $24.4 \mathrm{~mm}$ (II) to $34.4 \mathrm{~mm}$ (III). The preparation of the archive data was necessary as input data for the model used in the simulations. Both dry and most humid months are visible.

The hourly meteorological data (the temperature, the humidity, and the atmospheric pressure) used for estimation of water recovery from exhaust air by cross-flow heat exchanger conducted in Part 1 [4] was gained from the Institute of Meteorology and Water Management, National Research Institute stations. The available period was the years 2012-2019 (8 years). The data are shown in Part 1 of this research [4]. 

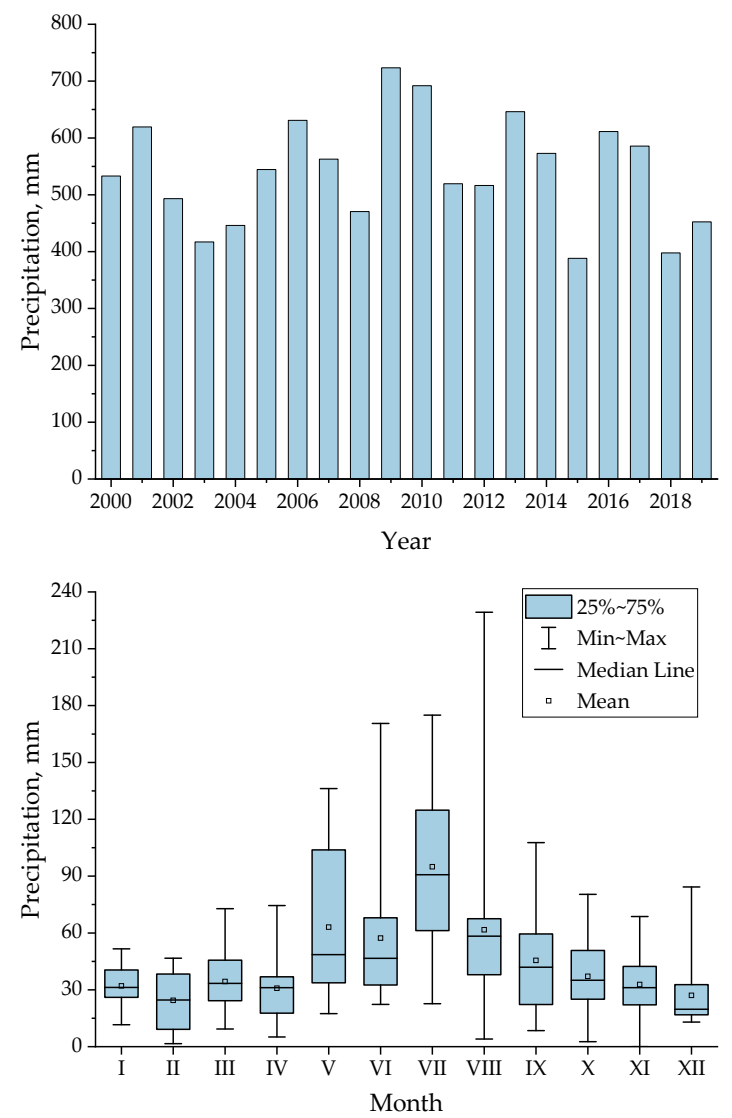

Figure 1. Annual and average monthly rainfall amounts in Wrocław in the years 2000-2019.

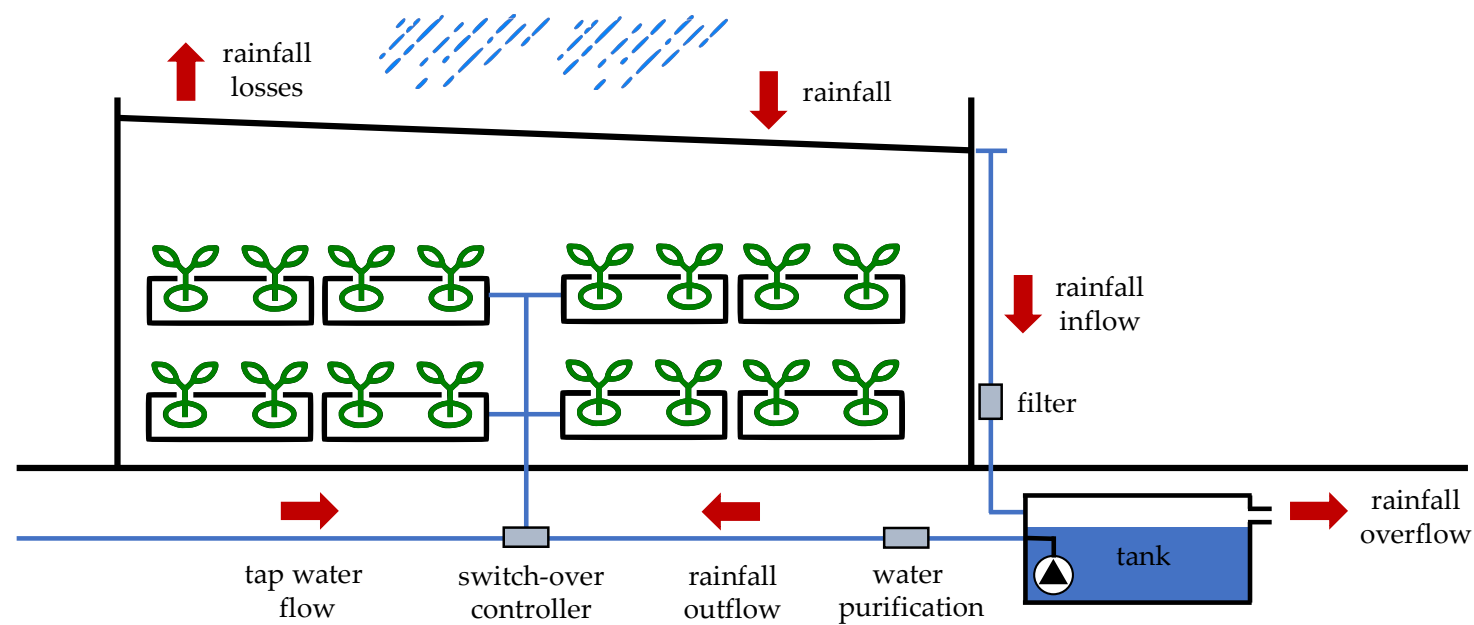

Figure 2. The diagram of the water flow in the rainwater harvesting system.

2.2. Description of the Vertical Indoor Farming Facility and Set-Up Parameters of the Growing Plants

A production hall (20 $\mathrm{m}$ long and $15 \mathrm{~m}$ wide) located in Wrocław was used for the calculations. The assumptions and extensive description of cultivation are presented in Part 1 of this study [4]. Cultivation is assumed to be year-round, with production on an ongoing basis. All calculations concerning water demand and other conditions for lettuce cultivation are based on Anderson et al. [23]. 


\subsection{Tank Capacity and Water Balance Model}

Dimensioning rainwater tanks in Polish hydrological conditions is relatively simple. It is usually assumed that for every $25 \mathrm{~m}^{2}$ of the area from which rainwater is collected, the tank should be able to store $1 \mathrm{~m}^{3}$ of water. Additionally, the time of storing water in the tank should not be longer than 2-3 weeks [24].

In the study analyzed in this manuscript, the area of the roof from which rainwater could be collected was $300 \mathrm{~m}^{2}$. In accordance with the above, a tank with a capacity of $12 \mathrm{~m}^{3}$ was selected, which, at a consumption of $1030 \mathrm{dm}^{3}$ per day, will guarantee a water retention time in the tank not longer than 11 days. In order to verify the selection of the tank size, the research was extended to include a comparison of different tank storage capacities, and their influence on cost-benefit analysis. Four different sizes were selected for further examination. Both, smaller and larger tank volumes were chosen $(6,9,15$, and $18 \mathrm{~m}^{3}$ ).

The water balance model was run to evaluate the hypothetical rainwater harvesting (RWH) system, taking into account the 20-year daily rainfall data, runoff capture, rainwater storage, and water demand. The water balance model was operated in a day-step mode, as described in the diagram in Figure 2.

The other water balance model was run to evaluate the hypothetical combined RWH system with water recovery from the exhaust air system presented in Figure 3. A cross-flow exchanger operating in air-conditioning systems was proposed as an element for heat recovery, which would enable additional water recovery from the exhaust air. The contact of humid exhaust air with the cold plate (lower than the dew point of the exhaust air) of the exchanger caused water vapor to accumulate in the air condensation in the exhaust air channels. The low plate temperature was the result of its contact with the ambient air. In calculations, the 8-year period of the actual parameters of the ambient air in Wrocław was taken into account.

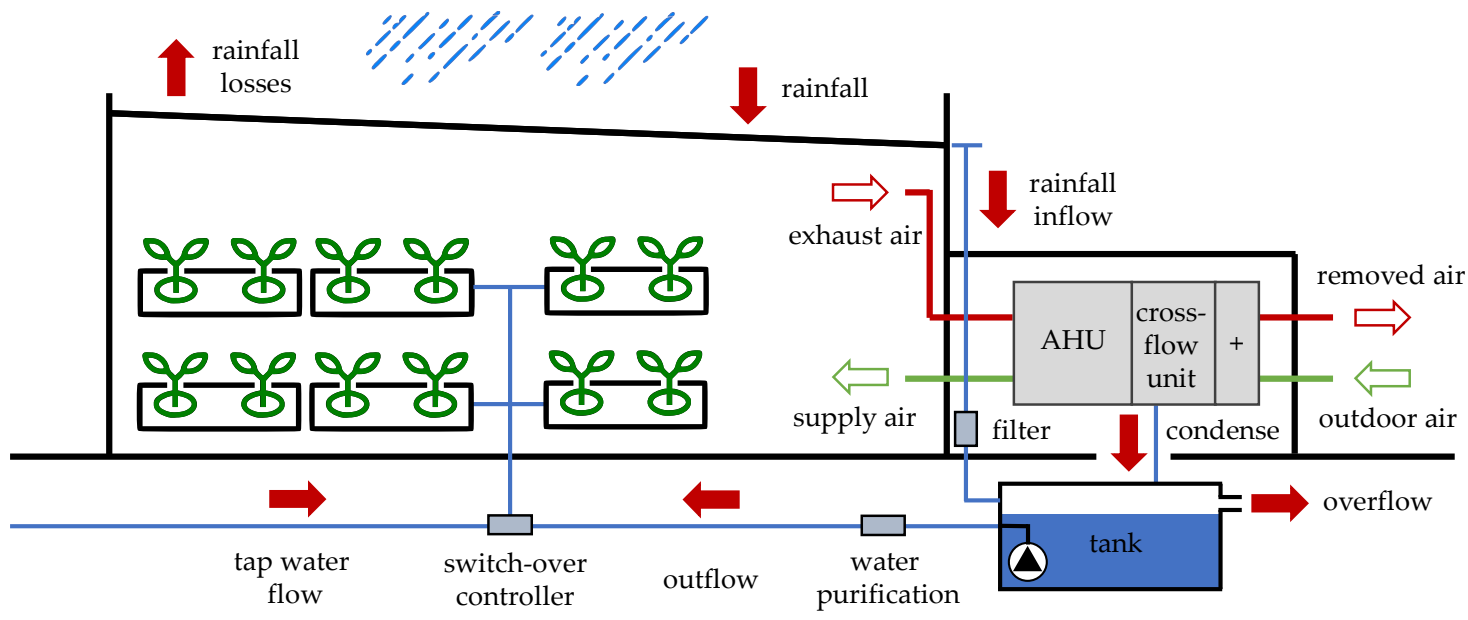

Figure 3. The diagram of the water flow in the rainwater harvesting system cooperating with water recovery from the exhaust air.

The rainwater inflows were calculated based on the rainfall amounts, the rooftop area, and the surface runoff coefficient (0.95). The rainwater storage was determined as the in-, out-, and overflows balance in the tank volume. The RWH system performance was defined as a share of rainwater outflow in water demand, calculated based on Anderson et al. [23] and shown in Part 1 of this study [23]. In case of insufficiency of the rainwater outflow to meet the water demand, tap water flows were automatically supplied by a switch-over controller. The simulation took into consideration the rainwater losses and rainfall overflow.

In practice, two algorithms were often used to describe the behavior of the collecting system during a given time interval: the yield after a spillage (YAS) and the yield before a 
spillage (YBS). In this investigation, each simulation was tested by the YAS algorithm, in which the withdrawal occurred before the rainfall:

$$
\begin{array}{r}
Q_{D_{t}}=\max \left\{\begin{array}{c}
V_{t-1}+A \cdot R_{t}-S \\
0
\end{array}\right. \\
V_{t}=\min \left\{\begin{array}{c}
D_{t} \\
V_{t-1}
\end{array}\right. \\
V_{t}=\min \left\{\begin{array}{c}
V_{t-1}+A \cdot R_{t}-Y_{t} \\
S-Y_{t}
\end{array}\right.
\end{array}
$$

where, $Q_{D t}\left(\mathrm{~m}^{3}\right)$ is the volume discharged as overflow from the storage tank at time step $t, V_{t}\left(\mathrm{~m}^{3}\right)$ is the volume stored at time step $t, R_{t}(\mathrm{~m})$ is the rainfall at time $t, A\left(\mathrm{~m}^{2}\right)$ is impervious surface area $\left(\mathrm{m}^{2}\right), Y_{t}\left(\mathrm{~m}^{3}\right)$ is the yield of rainwater from the storage tank at time step $t, D_{t}\left(\mathrm{~m}^{3}\right)$ is the water demand at time step $t$, and $S\left(\mathrm{~m}^{3}\right)$ is the tank storage capacity.

To establish the water recovered from exhaust air quantity, the heat balance equations of the mathematical model were implemented into the original compute program in the MATLAB environment. Using the mathematical model, a black-box model was developed to determine the operating parameters of the cross-flow unit. For the actual parameters of the ambient air in Wrocław in 2012-2019, the operation of the exchanger (dry heat exchange and condensation of water vapor in the exhaust air ducts) was simulated, including the necessity to protect the exchanger against freezing (air preheating).

The amount of recovered water was calculated using the equation (where $x_{i}$-inlet air humidity ratio, $x_{0}$ - outlet air humidity ratio, $V$-airflow $\left(\mathrm{m}^{3} / \mathrm{s}\right)$ and $\rho_{w}$-water density $\left.\left(\mathrm{kg} / \mathrm{m}^{3}\right)\right) \rho_{\text {air }}$-air density $\left(\mathrm{kg} / \mathrm{m}^{3}\right)$.

$$
w=\frac{V \rho_{a i r}\left(x_{2 i}-x_{2 o}\right)}{\rho_{w}}
$$

The usual indicator used to evaluate the performance of a rainwater collecting system is water-saving efficiency $(E)$. It was equal to the percentage of the overall demand supplied by the tank and it is given by the following equation [25]:

$$
E=\frac{\sum_{t-1}^{T} Y_{t}}{\sum_{t-1}^{T} D_{t}} \cdot 100
$$

where $T$ is the total time period under consideration and $R_{t}$ is the overall water savings that can be achieved by harvesting and using rainwater. Equation (4) provided a measure of how much water had been conserved in comparison to the overall demand and is also referred to as water-saving efficiency [26].

By using the indicator above, it can be determined whether the collection system is efficient and beneficial. However, for extended profitability analysis, the efficiency of the designed water source should be assessed. Such a procedure allowed us to determine whether it was possible to reduce associated infrastructure costs (i.e., size of pipes, pumps, wastewater treatment plant). For example, if the water source was reliable and satisfied the demand for a sufficient amount of water, it was possible to reduce the size of the associated infrastructure and thus lower investment costs. The efficiency estimation could be conducted using an "efficiency curve", and three efficiency indicators (RI) [25]. The first RI1 was described as the percentage of days the tank supplied 100\% of the demand. The second RI2 was featured as the percentage of days the tank supplied less than $10 \%$ of the water demand. The third RI3 was the percentage of water supplied by the tank over $90 \%$ of the days of the simulation, which meant the lowest daily water-saving efficiency. It was estimated by calculation of the daily water-saving efficiency $\left(Y_{t} / D_{t}\right)$ for all the days in the series. 
It should be noted, that the first two indicators were described as a percentage of days, while the third was a percentage of water demand supplied. Reducing the size of the infrastructure was not possible when RI1 was too small, or RI2 was too great since it suggested that the examined water source was not robust. The possible reliable demand reduction might be assessed with RI3 [25].

\section{Results}

\subsection{Analysis of Efficiency}

A preliminary analysis was carried out in order to examine the effect of the tank capacity $S$ on the daily efficiency $E$ and to identify whether the volume of the storage tank was selected correctly. All simulations were repeated for four additional volumes $(6,9,15$, $18 \mathrm{~m}^{3}$ ) in the years 2000-2019, and 2012-2019 for the RWH system, and the RWH system assisted by water recovery from the exhaust air system, respectively. The results of the simulation are presented in Figure 4. Water balance simulations were performed at a daily scale, thus accounting for the effect of extreme rainfall of $24 \mathrm{~h}$ duration and dry spells on the RWH system. For any tank size in each system configuration, the daily average $E$ was computed on the entire analysis period assumed in calculations.

(A)

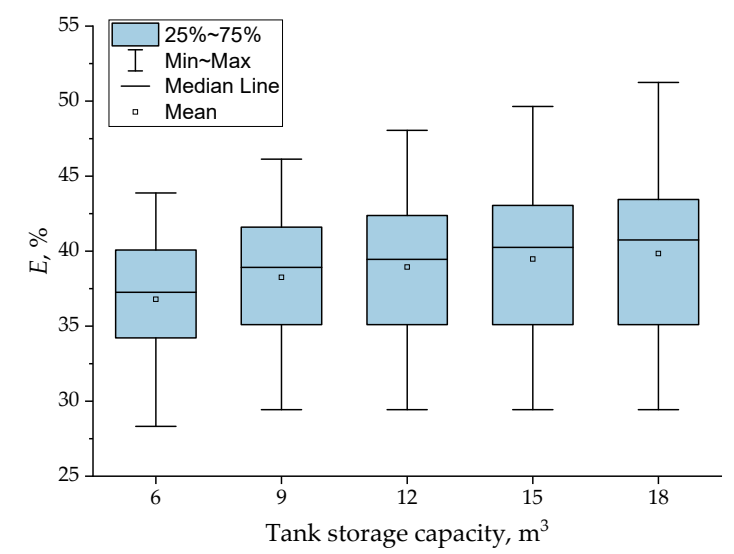

(B)

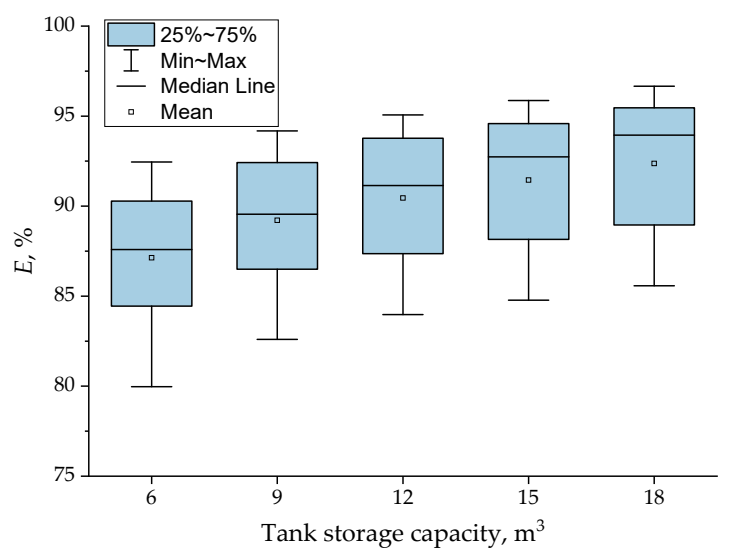

Figure 4. Comparison of the water-saving efficiency with different tank storage capacity for the rainwater harvesting (RWH) system (A), and the RWH system cooperating with water recovery from the exhaust air (B).

The amount of water demand for indoor hydroponic lettuce cultivation was approximately $376.2 \mathrm{~m}^{3}$ per year. The annual efficiency of the RWH system and the RWH system working with water recovery from the exhaust air system was assessed as an average of the annual $E$ values related to the analyzed period of twenty years, or eight years, respectively. Focusing on the mean, the average daily $E$ would grow with tank capacity: For sizes ranging between 6 and $18 \mathrm{~m}^{3}$, $E$ varied in the range from $36.8 \%$ to $39.8 \%$ for the $\mathrm{RWH}$ system working individually (Figure $4 \mathrm{~A}$ ), and varied in the range from $87.1 \%$ to $92.4 \%$ for the combined system (Figure 4B).

Although the percentage differences were small, they resulted in saving several cubic meters of water per year and increased the independence of the cultivation from the water supply network. It was more beneficial to choose smaller tanks regarding the economic analysis (see Section 3.2. Cost-Benefit Analysis) while taking into account the ecological analysis on the contrary. The larger tanks provided greater buffer capacity and reduced the amount of discharged water to the sewer. The final decision should be made on the basis of a trade study taking into account all the aspects (economic and ecological analysis, the location of the indoor farm, etc.).

The analysis was performed in relation to RI1, RI2, and RI3 for a $12 \mathrm{~m}^{3}$ tank (as an example size) for both configurations. The results are shown in Figure 5. 
(A)

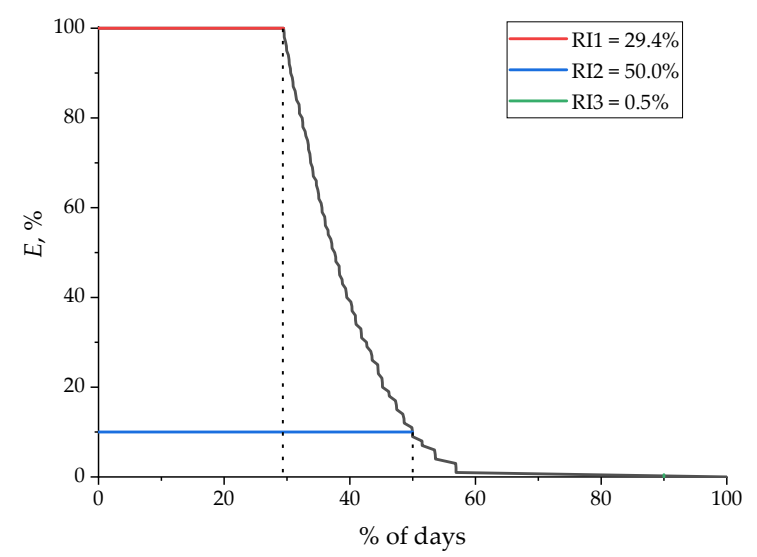

(B)

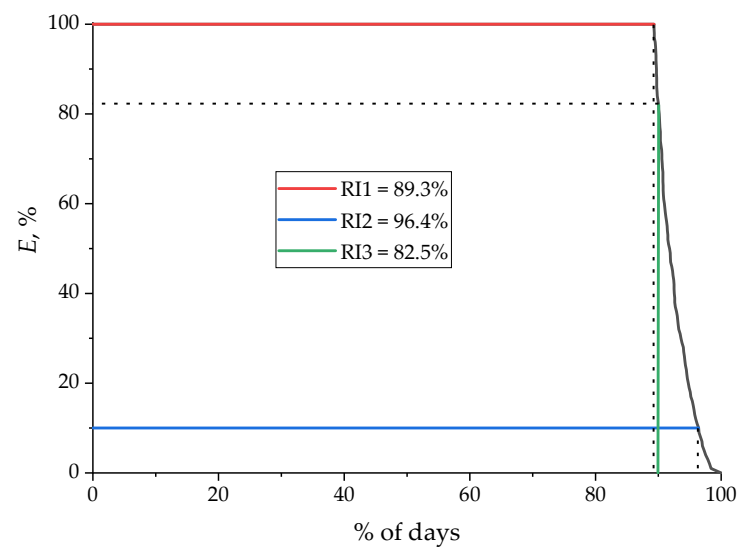

Figure 5. The efficiency curve for a simulation of a separate RWH system (A), and a combined system (B).

As can be seen, the RWH system could only assure total water demand coverage for $29.4 \%$ of the days of the analyzed period (RI1, Figure 5A). It could be increased about three times when combining it with water recovery from the exhaust air system (RI1, Figure 5B). The tank supplied a minimum of $10 \%$ of the water demand for $50 \%$ of days with the singular RWH system, while $96.4 \%$ with the combined system (RI2). The biggest difference between the configurations could be seen in the RI3 indicator. The lowest daily water-saving efficiency for the RWH system was incomparably smaller than the combined configuration.

The results showed that the RWH system alone allowed us to save water, but it would not be a sufficiently reliable source of water and would not reduce the investment costs of other infrastructure. However, while implementing the combined system, the efficiency increased drastically. This configuration enabled both water savings and investment cost savings, due to the decreased size of external water supply infrastructure.

Figure $6 \mathrm{~A}$ shows a plot of mean monthly demand, rainfall volumes, and yield over the simulation period, while Figure $6 \mathrm{~B}$ presents the corresponding monthly variation in efficiency $E$. Water demand for lettuce irrigation was clearly unaffected by monthly and seasonal variations, and showed only slight differences from month to month (on the order of $1 \mathrm{~m}^{3}$ ), while rainfall volumes were seasonal. In the case of rainwater recovery, the maximum mean rainfall was observed in July (VII), which was a higher value than the yield (tank capacity $S=12 \mathrm{~m}^{3}$ ) and a lower value than the water demand for lettuce irrigation in the indoor vertical farm. Rainfall volumes were highest during the summer months from May to September (Figure 6A). From July onward, the average rainfall dropped sharply until the end of the year. The minimum value of demand, yield, and rainfall volume was reached in February. The maximum and minimum system efficiency equaled $69.6 \%$ and $23.1 \%$ respectively (see Figure $6 \mathrm{~B}$ ), hence this water recovery system is not self-sufficient.

Figure 7 presents a combined system consisting of rainfall and exhaust air water recovery performance. When demand and yield overlapped or the yield exceeded the demand, the combined system met the water demand for lettuce irrigation, ensuring efficiency of $100 \%$ during 7 months of operation (from January to May and in November and December). During those months, the water recovery exceeded the yield significantly (Figure 7B). In January, there was a maximum water recovery (about three times higher than the yield and water demand). When the water demand exceeded the yield in June, July, and August, it caused low monthly $E$ values. The minimum system efficiency was observed in August (59\%). It could be noticed that the proposed combined system had high annual efficiency and was self-sufficient for most of the year compared to the rainwater recovery system only. 
(A)

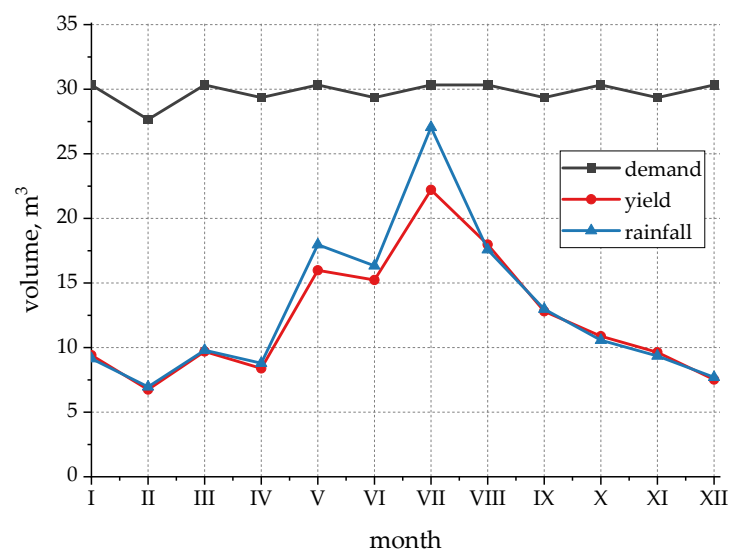

(B)

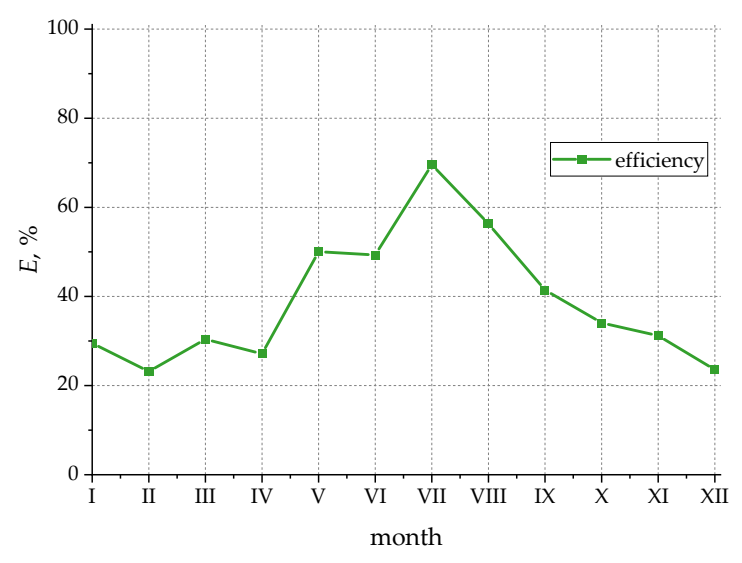

Figure 6. Mean monthly characteristics of individual rainwater recovery system. For tank capacity $S=12 \mathrm{~m}^{3}$. (A) Water demand, rainfall volume, and yield. (B) Monthly variation of system efficiency.

(A)

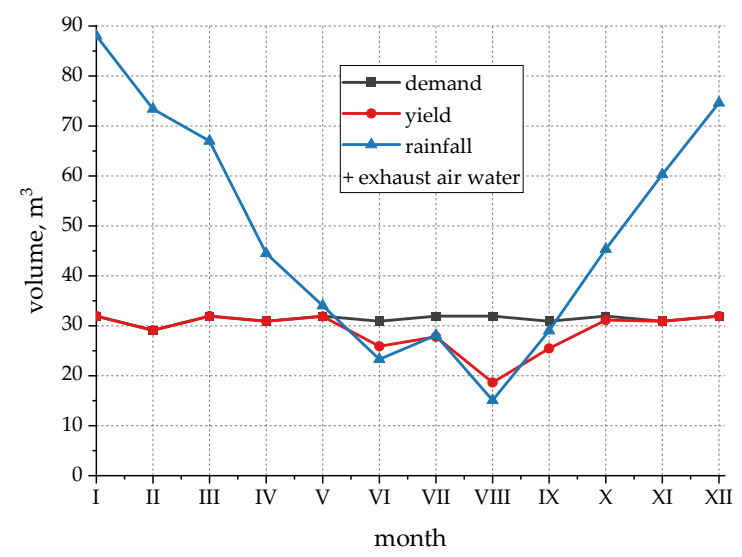

(B)

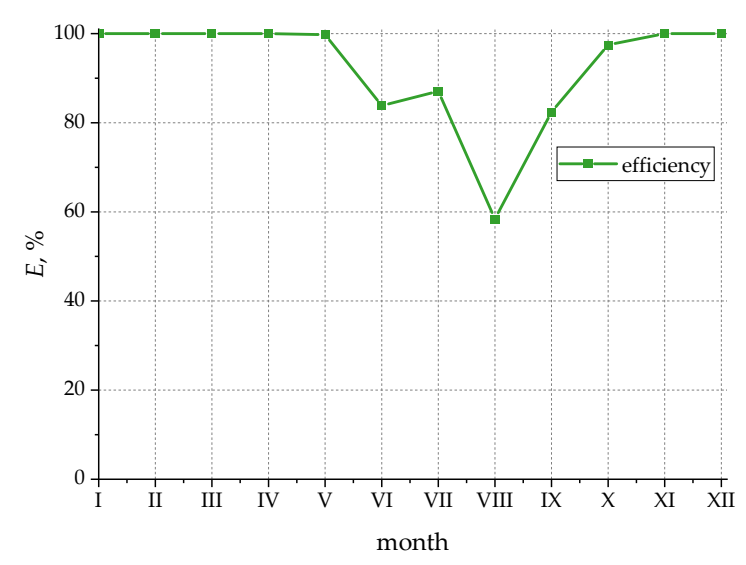

Figure 7. Mean monthly characteristics of combined water recovery system. For tank capacity $S=12 \mathrm{~m}^{3}$. (A) Water demand, rainfall volume, and yield. (B) Monthly variation of system efficiency.

\subsection{Cost-Benefit Analysis}

An economic analysis of the RWH system was carried out in order to investigate the balance between the investment/cost for system purchase and installation, and the benefits obtained by the rainwater use for indoor hydroponic lettuce cultivation. To this aim, a schematic underground installation of a RWH system was considered, consisting of a pre-fabricated concrete tank provided with a first flush device, a manhole with a rainwater filter, a pumping system, and its Programmable Logic Controller (PLC) equipment, the drainage piping system inlet and outlet, the tank, and the piping distribution system to supply the rainwater for the analyzed uses. Table 1 summarizes the costs of the RWH system elements for each tank capacity. These costs were obtained by means of a market survey. In the case of the combined system, the costs are higher, since the installation of water collection from the exchanger must be included. 
Table 1. Net present value (NPV) and payback period $(P B P)$ values related to each tank size for the RWH system.

\begin{tabular}{|c|c|c|c|c|c|}
\hline $\begin{array}{c}\text { Tank } \\
\text { Volume, } \mathrm{m}^{3}\end{array}$ & Costs, $€$ & $\begin{array}{c}\text { Water-Saving, } \\
\mathrm{m}^{3} / \text { Year }\end{array}$ & Annual $E, \%$ & $\begin{array}{c}N P V \\
\text { (20 Years), } €\end{array}$ & $P B P$, Year \\
\hline \multirow{3}{*}{6} & \multirow{3}{*}{2654} & 106 (min.) & 28.3 & 1150 & 16 \\
\hline & & 138 (av.) & 36.8 & 2292 & 13 \\
\hline & & 165 (max.) & 43.9 & 3240 & 11 \\
\hline \multirow{3}{*}{9} & \multirow{3}{*}{2863} & 111 (min.) & 29.4 & 1092 & 16 \\
\hline & & 144 (av.) & 38.3 & 2279 & 13 \\
\hline & & 173 (max.) & 46.1 & 3335 & 12 \\
\hline \multirow{3}{*}{12} & \multirow{3}{*}{3017} & 111 (min.) & 29.4 & 938 & 17 \\
\hline & & 147 (av.) & 38.9 & 2219 & 14 \\
\hline & & 181 (max.) & 48.0 & 3438 & 12 \\
\hline \multirow{3}{*}{15} & \multirow{3}{*}{3362} & 111 (min.) & 29.4 & 593 & 18 \\
\hline & & 149 (av.) & 39.5 & 1945 & 15 \\
\hline & & 187 (max.) & 49.6 & 3308 & 12 \\
\hline \multirow{3}{*}{18} & \multirow{3}{*}{3516} & 111 (min.) & 29.4 & 439 & 19 \\
\hline & & 150 (av.) & 39.8 & 1841 & 15 \\
\hline & & 193 (max.) & 51.2 & 3368 & 13 \\
\hline
\end{tabular}

In the present analysis, the costs related to system maintenance were considered negligible when compared to purchase and installation costs [27]. With regard to the benefits related to the RWH system installation, only the financial benefits due to the potable water saving were considered. In this analysis, environmental and social benefits were not accounted for. Two performance indicators, the Net Present Value (NPV) and the payback period $(P B P)$ were evaluated $[27,28]$. In the analysis, the following assumptions were made:

- $\quad$ The evaluation period to assess the NPV was set equal to 20 years [28,29];

- according to [30], a discount rate of $5 \%$ had been assumed;

- the inflation rate had been assumed equal to $4.5 \%$ (on the basis of the inflation rate of potable water price in Wrocław in recent years);

- the actual price for potable water had been set equal to $1.2 € / \mathrm{m}^{3}$ (the actual prices adopted by water utilities operating in Wrocław).

The effect of the variability of annual yield had been accounted for in the $P B P$ and the NPV appraisal, considering the minimum, the maximum, and the mean annual yield. Results of both systems analysis are shown in Tables 1 and 2 for each tank size.

It can be seen in Table 1 that from the perspective of saving water when collecting rainwater, the smaller reservoir had the lowest annual average $E=36.8 \%$ and the largest, the highest $E=39.8 \%$. Table 1 also summarizes the average payback period of a tank, which equaled 13 years (bolded) both for $6 \mathrm{~m}^{3}$ and $9 \mathrm{~m}^{3}$. By using those reservoir sizes over 20 years, respectively $€ 2292$ and $€ 2279$ may be saved. The performed analysis showed that tanks larger than $9 \mathrm{~m}^{3}$ were associated with a longer payback period and a lower $N P V$, which in the case of a volume $18 \mathrm{~m}^{3}$, the minimum value was $€ 1841$. The annual $E$ and water-saving increased with the tank size increment, hence for only rainwater recovery, including the economic indicators, the reservoir $8 \mathrm{~m}^{3}$ was proposed. The selected economic efficiency indicators for the combined water recovery system are presented in Table 2. In general, the combined system reached much more favorable values of $N P V$ and $P B P$ than the system with only rainwater recovery.

According to the presented data, the most economically profitable solution in terms of $P B P$ was using tanks with smaller volumes (e.g., $6 \mathrm{~m}^{3}$ ). The cost of the tank depends on its size and the smaller tank has a cheaper price, hence a system with a $6 \mathrm{~m}^{3}$ tank over 20 years saved $€ 8615$, and it had the shortest payback period equal to 7 years (bolded). 
Nevertheless, the volume of a tank equal to $12 \mathrm{~m}^{3}$ represented the highest $N P V=$ $€ 8698$, a higher annual $E=90.4 \%$, and higher water savings compared to smaller tanks. For example, the largest analyzed reservoir $\left(18 \mathrm{~m}^{3}\right)$ had returned within 9 years (bolded) but its annual efficiency was the highest $(92.4 \%)$. That is why the $12 \mathrm{~m}^{3}$ tank was chosen for the combined system's effective operation. It is worth mentioning that the combined system's average annual efficiency, depending on the size of the reservoir, was in a wider range (from $87.1 \%$ to $92.4 \%$ ) than was the case of the system with only rainwater recovery (from $36.8 \%$ to $38.8 \%$ ).

Table 2. NPV and PBP values related to each tank size for the combined system.

\begin{tabular}{|c|c|c|c|c|c|}
\hline $\begin{array}{c}\text { Tank } \\
\text { Volume, } \text { m }^{3}\end{array}$ & Costs, $€$ & $\begin{array}{c}\text { Water-Saving, } \\
\mathrm{m}^{3} / \text { Year }\end{array}$ & Annual $E, \%$ & $\begin{array}{c}N P V \\
\text { (20 Years), } €\end{array}$ & $P B P$, Year \\
\hline \multirow{3}{*}{6} & \multirow{3}{*}{3099} & 301 (min.) & 80.0 & 7644 & 8 \\
\hline & & 328 (av.) & 87.1 & 8615 & 7 \\
\hline & & 349 (max.) & 92.5 & 9356 & 7 \\
\hline \multirow{3}{*}{9} & \multirow{3}{*}{3307} & 311 (min.) & 82.6 & 7789 & 8 \\
\hline & & 336 (av.) & 89.2 & 8686 & 8 \\
\hline & & 355 (max.) & 94.2 & 9379 & 7 \\
\hline \multirow{3}{*}{12} & \multirow{3}{*}{3461} & 316 (min.) & 84.0 & 7820 & 8 \\
\hline & & 340 (av.) & 90.4 & 8698 & 8 \\
\hline & & 358 (max.) & 95.1 & 9346 & 8 \\
\hline \multirow{3}{*}{15} & \multirow{3}{*}{3806} & 319 (min.) & 84.8 & 7583 & 9 \\
\hline & & 344 (av.) & 91.4 & 8488 & 8 \\
\hline & & 361 (max.) & 95.9 & 9108 & 8 \\
\hline \multirow{3}{*}{18} & \multirow{3}{*}{3960} & 322 (min.) & 85.6 & 7536 & 9 \\
\hline & & 348 (av.) & 92.4 & 8458 & 9 \\
\hline & & 364 (max.) & 96.7 & 9061 & 8 \\
\hline
\end{tabular}

\section{Discussion}

On the basis of the performed rainwater harvesting system analysis, the use of rainwater may be a feasible alternative to tap water for hydroponic lettuce cultivation located in Wroclaw only during the summer months, in particular in July and August. For example, in the case of a tank size of $12 \mathrm{~m}^{3}$ during those months, the system efficiency equals $69.6 \%$ and $56.3 \%$, respectively. In the winter months, the rainwater harvesting system efficiency is $23.6 \%$ (in December), $29.5 \%$ (in January), and 23.1\% (in February). The smaller tank provides lower efficiency and minimal payback period, which equals 13 years both for $6 \mathrm{~m}^{3}$ and $9 \mathrm{~m}^{3}$ tanks. By using those reservoir sizes, respectively $€ 2292$ and $€ 2279$ may be saved over 20 years. The larger tanks will provide greater buffer capacity and reduce the amount of discharged water to the sewer. The final decision should be made on the basis of a trade study taking into account all the aspects (economic and ecological analysis, the location of the indoor farm, etc.). One must emphasize here that for such selected water reservoir parameters, in practice, the rainwater only goes into the sewage system when there is very heavy precipitation, with daily totals exceeding $40 \mathrm{~mm}$. This allows the reservoir to hydraulically relieve the rainfall drainage system, in this way reducing its hydraulic overload. Such a solution significantly reduces the pluvial flash floods phenomenon [31-33], as rainwater management is one of the most efficient methods of limiting city floods occurring in Poland during the warmer half of the year. In this study, for the rainwater harvesting system, the $6 \mathrm{~m}^{3}$ tank volume is recommended to obtain low $P B P$ and the highest $N P V$.

Due to the rainwater recovery system giving the best results in the warmer half of the year and the exhaust air water recovery system working best during the colder half of the year, an attempt has been made to combine these solutions. An initially selected volume of a $12 \mathrm{~m}^{3}$ reservoir allows, on the one hand, during heavy precipitations, for the accumulation of water in the reservoir for a few days, but on the other hand, due to a 
large water demand (1030 L/day), there is no possibility of the water remaining in the reservoir for a dry period longer than 11 days. Such a solution allows us to maximize the volume of the accumulated water, simultaneously reducing the operational issues related to the quality of the accumulated water. The proposed combined system ensures efficiency of $100 \%$ during 7 months of operation (from Jan to May and in Nov and Dec). During those months, the water recovery exceeds the yield significantly. In January, the system presents a maximum water recovery (about three times higher than the yield and water demand). To check the correctness of the selection of the $12 \mathrm{~m}^{3}$ tank for the combined system, an economic analysis was performed. In comparison to other tank volumes, the $12 \mathrm{~m}^{3}$ tank over 20 years allows maximal savings of $€ 8698$, with a satisfactory payback period equal to 8 years. Additionally, system arrangement with a $12 \mathrm{~m}^{3}$ tank has a higher efficiency than smaller tanks. It covers, on average, as much as $90.4 \%$ of the water demand (340.0 $\mathrm{m}^{3}$ per year). The minimum yearly water demand coverage $(84.0 \%$, corresponding to a volume of $316.0 \mathrm{~m}^{3}$ ) was achieved in 2018 while the maximum annual coverage $(95.1 \%$, corresponding to a volume of $358.0 \mathrm{~m}^{3}$ ). It can be noticed that the combined system has high annual efficiency and is self-sufficient for most of the year compared to using the rainwater recovery system only.

\section{Summary and Conclusions}

In times when it is necessary to recover water and relieve the pressure on water supply networks, alternative sources of water are being sought. A previous study gave an analysis of water recovery from the exhaust air for a cultivation hall. This system was not self-sufficient, because its effectiveness in the warmer period was very low. In areas with rainfall, rainwater recovery is popular, thus it is important to analyze its effectiveness for water supply to hydroponics. In this work, for the selected location (Wrocław, Poland) and the assumed geometry of the plant hall, the effectiveness of rainwater recovery from the roof surface was analyzed. The calculations of the rainwater harvesting (RWH) system were carried out, considering the selection of the tank capacity for the collected water. The operation of the water storage was simulated using a yield after spillage (YAS) algorithm. It was evident that the proposed system might be an auxiliary system that relieves the water supply network or supports other water recovery systems (e.g., the water vapor condensation in a cross-flow heat exchanger operating as an element of the air conditioning system, proposed in Part 1 of this study). On the base of long term water recovery systems analysis, the rainwater harvesting system is a less stable source of water than water reclaimed from the air, comparing to the system recovering water from the exhausted air [4].

In the summer season, the greatest effectiveness of rainwater recovery was observed. The annual average water-saving efficiency from the RWH system equaled $38.94 \%$ while the condense recovery system's effectiveness equaled $67.12 \%$. Taking into account the relatively high effectiveness of the rainwater recovery system during the summer, a solution based on combining the two systems was proposed. An economic analysis of the combined system with a $12 \mathrm{~m}^{3}$ tank was proposed which achieved an average water recovery for plant watering purposes equal to $90.4 \%$. In 2018, there was a minimum water coverage of $84.0 \%$. In 2012 , there was a maximum water demand coverage of $95.1 \%$. It may be concluded that a combination of both of the systems is a very efficient solution, allowing for a large reduction in tap water consumption for hydroponic lettuce cultivation.

Author Contributions: A.J., A.P. and B.K.; investigation, A.J., A.P.; resources, B.K.; data curation, B.K.; writing—original draft preparation, A.J., A.P., D.P. and B.K.; writing—review and editing, A.J., A.P., D.P. and B.K.; visualization, B.K.; supervision, D.P.; project administration, A.P.; funding acquisition, A.P. and B.K. All authors have read and agreed to the published version of the manuscript.

Funding: Anna Pacak and Demis Pandelidis received financial support from Polish National Centre for Research and Development, pro-gram Lider X, agreement number U/0180/666/2019.

Institutional Review Board Statement: Not applicable. 
Informed Consent Statement: Not applicable.

Acknowledgments: In this section you can acknowledge any support given which is not covered by the author contribution or funding sections. This may include administrative and technical support, or donations in kind (e.g., materials used for experiments).

Conflicts of Interest: The authors declare no conflict of interest.

\section{References}

1. Avgoustaki, D.D.; Xydis, G. Plant factories in the water-food-energy Nexus era: A systematic bibliographical review. Food Secur. 2020, 12, 253-268. [CrossRef]

2. Jones, J.B., Jr. Complete Guide for Growing Plants Hydroponically, 1st ed.; CRC Press: Boca Raton, FL, USA; Taylor \& Francis Group: Boca Raton, FL, USA, 2014; pp. 1-206.

3. Kalantari, F.; Tahir, O.M.; Lahijani, A.M.; Kalantari, S. A Review of Vertical Farming Technology: A Guide for Implementation of Building Integrated Agriculture in Cities. Adv. Eng. Forum 2017, 24, 76-91. [CrossRef]

4. Pacak, A.; Jurga, A.; Drag, P.; Pandelidis, D.; Kaźmierczak, B. A Long-Term Analysis of the Possibility of Water Recovery for Hydroponic Lettuce Irrigation in Indoor Vertical Farm. Part 1: Water Recovery from Exhaust Air. Appl. Sci. 2020, 10, 8907. [CrossRef]

5. Canales, F.A.; Gwoździej-Mazur, J.; Jadwiszczak, P.; Struk-Sokołowska, J.; Wartalska, K.; Wdowikowski, M.; Kaźmierczak, B. Long-Term Trends in 20-Day Cumulative Precipitation for Residential Rainwater Harvesting in Poland. Water 2020, $12,1932$. [CrossRef]

6. Orlińska-Woźniak, P.; Wilk, P.; Gębala, J. Water availability in reference to water needs in Poland. Meteorol. Hydrol. Water Manag. 2014, 1, 45-50. [CrossRef]

7. Lam, K.L.; Kenway, S.J.; Lant, P.A. Energy use for water provision in cities. J. Clean. Prod. 2017, 143, 699-709. [CrossRef]

8. Torregrossa, D.; Capitanescu, F. Optimization models to save energy and enlarge the operational life of water pumping systems. J. Clean. Prod. 2019, 213, 89-98. [CrossRef]

9. Hofmann, J.; Schüttrumpf, H. Risk-Based Early Warning System for Pluvial Flash Floods: Approaches and Foundations. Geosciences 2019, 9, 127. [CrossRef]

10. Kron, W.; Eichner, J.; Kundzewicz, Z. Reduction of flood risk in Europe-Reflections from a reinsurance perspective. J. Hydrol. 2019, 576, 197-209. [CrossRef]

11. Ri, S.D.; Favargiotti, S.; Albatici, R. The role of vertical farming in re-thinking and re-designing cities within a circular perspective. Riv. Tema 2020, 6, 96-106. [CrossRef]

12. Amos, C.C.; Rahman, A.; Karim, F.; Gathenya, J.M. A scoping review of roof harvested rainwater usage in urban agriculture: Australia and Kenya in focus. J. Clean. Prod. 2018, 202, 174-190. [CrossRef]

13. Ngigi, S.N.; Savenije, H.H.; Rockström, J.; Gachene, C.K. Hydro-economic evaluation of rainwater harvesting and management technologies: Farmers' investment options and risks in semi-arid Laikipia district of Kenya. Phys. Chem. Earth Parts A/B/C 2005, 30, 772-782. [CrossRef]

14. Stout, D.T.; Walsh, T.C.; Burian, S.J. Ecosystem services from rainwater harvesting in India. Urban Water J. 2017, 14, 561-573. [CrossRef]

15. Lupia, F.; Pulighe, G. Water Use and Urban Agriculture: Estimation and Water Saving Scenarios for Residential Kitchen Gardens. Agric. Agric. Sci. Procedia 2015, 4, 50-58. [CrossRef]

16. Cook, S.; Sharma, A.; Chong, M. Performance Analysis of a Communal Residential Rainwater System for Potable Supply: A Case Study in Brisbane, Australia. Water Resour. Manag. 2013, 27, 4865-4876. [CrossRef]

17. Woltersdorf, L.; Liehr, S.; Doell, P. Rainwater Harvesting for Small-Holder Horticulture in Namibia: Design of Garden Variants and Assessment of Climate Change Impacts and Adaptation. Water 2015, 7, 1402-1421. [CrossRef]

18. Parsons, D.; Goodhew, S.; Fewkes, A.; De Wilde, P. The perceived barriers to the inclusion of rainwater harvesting systems by UK house building companies. Urban Water J. 2010, 7, 257-265. [CrossRef]

19. Liuzzo, L.; Notaro, V.; Freni, G. A Reliability Analysis of a Rainfall Harvesting System in Southern Italy. Water 2016, 8, 18. [CrossRef]

20. Campisano, A.; Butler, D.; Ward, S.; Burns, M.J.; Friedler, E.F.; DeBusk, K.; Fisher-Jeffes, L.N.; Ghisi, E.; Rahman, A.; Furumai, H.; et al. Urban rainwater harvesting systems: Research, implementation and future perspectives. Water Res. 2017, 115, 195-209. [CrossRef]

21. Campisano, A.; Gnecco, I.; Modica, C.; Palla, A. Designing domestic rainwater harvesting systems under different climatic regimes in Italy. Water Sci. Technol. 2013, 67, 2511-2518. [CrossRef]

22. Sørup, H.J.D.; Lerer, S.M.; Arnbjerg-Nielsen, K.; Mikkelsen, P.S.; Rygaard, M. Efficiency of stormwater control measures for combined sewer retrofitting under varying rain conditions: Quantifying the Three Points Approach (3PA). Environ. Sci. Policy 2016, 63, 19-26. [CrossRef]

23. Anderson, M.S.; Ewert, M.K.; Keener, J.F.; Wagner, S.A. Life Support Baseline Values and Assumptions Document; National Aeronautics and Space Administration: Houston, TX, USA, 2018; pp. 1-233. 
24. Struk-Sokołowska, J.; Gwoździej-Mazur, J.; Jadwiszczak, P.; Butarewicz, A.; Ofman, P.; Wdowikowski, M.; Kaźmierczak, B. The Quality of Stored Rainwater for Washing Purposes. Water 2020, 12, 252. [CrossRef]

25. Gires, A.; De Gouvello, B. Consequences to water suppliers of collecting rainwater on housing estates. Water Sci. Technol. 2009, 60, 543-553. [CrossRef] [PubMed]

26. Fewkes, A.; Butler, D. Simulating the performance of rainwater collection and reuse systems using behavioural models. Build. Serv. Eng. Res. Technol. 2000, 21, 99-106. [CrossRef]

27. Khastagir, A.; Jayasuriya, N. Investment Evaluation of Rainwater Tanks. Water Resour. Manag. 2011, 25, 3769-3784. [CrossRef]

28. Matos, C.; Bentes, I.; Santos, C.; Alam Imteaz, M.; Pereira, S. Economic Analysis of a Rainwater Harvesting System in a Commercial Building. Water Resour. Manag. 2015, 29, 3971-3986. [CrossRef]

29. Zhang, Y.; Chen, D.; Chen, L.; Ashbolt, S. Potential for rainwater use in high-rise buildings in Australian cities. J. Environ. Manag. 2009, 91, 222-226. [CrossRef]

30. European Commission, Directorate General Regional Policy. Guide to Cost-Benefit Analysis of Investment projects-Structural Funds, Cohesion Fund and Instrument for Pre-Accession. Available online: http://ec.europa.eu/regional_policy/sources/ docgener/guides/cost/guide2008_en.pdf (accessed on 12 November 2015).

31. O'Donnell, E.; Thorne, C.; Ahilan, S.; Arthur, S.; Birkinshaw, S.; Butler, D.; Dawson, D.; Everett, G.; Fenner, R.; Glenis, V.; et al. The blue-green path to urban flood resilience. Blue-Green Syst. 2019, 2, 28-45. [CrossRef]

32. Jegatheesan, V.; Goonetilleke, A.; van Leeuwen, J.; Kandansamy, J.; Warner, D.; Myers, B.; Bhuiyan, M.; Spence, K.; Parker, G. Urban Stormwater and Flood Management: Enhancing the Liveability of Cities-Google Books; Springer: Berlin/Heidelberg, Germany, 2019.

33. Jamali, B.; Bach, P.M.; Deletic, A. Rainwater harvesting for urban flood management-An integrated modelling framework. Water Res. 2020, 171, 115372. [CrossRef] 